$5-1-2010$

\title{
Nonlinear Politics Perceptions-Work Outcomes Relationships: A Three-Study, Five-Sample Investigation
}

Vickie C. Gallagher

Cleveland State University, v.c.gallagher@csuohio.edu

Wayne A. Hochwarter

Florida State University, whochwar@cob.fsu.edu

Gerald R. Ferris

Florida State University

Mary D. Laird

University of Tulsa

Follow this and additional works at: https://engagedscholarship.csuohio.edu/bus_facpub

Part of the Business Administration, Management, and Operations Commons, and the Psychology

\section{Commons}

How does access to this work benefit you? Let us know!

\section{Publisher's Statement}

Vickie C. Gallagher, Wayne A. Hochwarter, Gerald R. Ferris, Mary D. Laird, Nonlinear Politics Perceptions-Work Outcomes Relationships: A Three-Study, Five-Sample Investigation. Journal of Management (36,3) pp. 740-763, doi:10.1177/0149206308324065. Copyright (C 2010 by Southern Management Association. Reprinted by permission of SAGE Publications, Inc.

\section{Original Published Citation}

Hochwarter, W.A., Ferris, G.R., Laird, M.D., Treadway, D.C., \& Gallagher, V.C. (2010). Nonlinear politics perceptions-work outcomes relationships: A three-study, five-sample investigation. Journal of Management, 36(3), 740-763, doi:10.1177/0149206308324065

This Article is brought to you for free and open access by the Monte Ahuja College of Business at EngagedScholarship@CSU. It has been accepted for inclusion in Business Faculty Publications by an authorized administrator of EngagedScholarship@CSU. For more information, please contact library.es@csuohio.edu. 


\title{
Nonlinear Politics Perceptions-Work Outcomes Relationships: A Three-Study, Five-Sample Investigation
}

\author{
Wayne A. Hochwarter \\ Gerald R. Ferris \\ Florida State University \\ Mary Dana Laird \\ University of Tulsa \\ Darren C. Treadway \\ State University of New York at Buffalo \\ Vickie Coleman Gallagher \\ Northern Kentucky University
}

This research reports the findings of three studies (involving a total of five samples) developed to explore the nonlinear relationships of organizational politics perceptions with practically and theoretically relevant work outcomes. Study 1 hypothesized a nonlinear relationship between organizational politics perceptions and job satisfaction. In Sample 1 of this study, a nonlinear relationship was identified, best depicted as an inverted-U form, and Sample 2 replicated this finding. Study 2 hypothesized a U-shaped relationship between politics perceptions and job tension, which was identified in Sample 3 and corroborated in Sample 4. In a single-sample investigation (i.e., Sample 5), Study 3 extended nonlinear conceptualizations by considering moderation (i.e., in the form of perceived resources) and, thus, the possibility of restricted nonlinearity. Results indicated that politics perceptions demonstrated a nonlinear association with job tension (i.e., $U$-shaped form) only for those with fewer perceived resources. For those with higher levels of perceived resources, no relationship between politics perceptions and job tension existed. Implications of these findings for scholarship and practice are offered.

Keywords: politics perceptions; nonlinearity; job satisfaction; job tension 
Organizational politics, which has been defined as "a subjective state in which organizational members perceive themselves or others as intentionally seeking selfish ends in an organizational context when such ends are opposed to those of others" (Gandz \& Murray, 1980: 248), has gone from an unmentioned, yet real, aspect of work life, to one that has amassed sizeable practical and scholarly attention (Buchanan, 2008; Ferris, Adams, Kolodinsky, Hochwarter, \& Ammeter, 2002). In terms of academic interest, considerable research has been conducted over the past 30 years to investigate predictors, moderators, and outcomes of politics perceptions-work outcomes relationships (Ferris, Russ, \& Fandt, 1989; Hochwarter, 2003a). In general, reviews have reported negative consequences of politics perceptions for workplace attitudes such as job satisfaction and work tension (Ferris et al., 2002; Kacmar \& Baron, 1999).

Despite the veracity of these results in this area, a number of unanswered questions remain (see Ferris et al., 2002). Particular to the current research is the consideration of politics perceptions-work outcomes relational forms. Specifically, disproportionate emphasis has been placed on the magnitude of substantive relationships to the neglect of form (Hochwarter, 2003b). Indeed, as a field of scientific inquiry, the organizational sciences have assumed that the preponderance of phenomena are related linearly (Ferris, Bowen, Treadway, Hochwarter, Hall, \& Perrewé, 2006). However, because there has been enough variability in previous studies and presumably in nonsignificant findings not submitted for publication (Rosenthal, 1979), it is appropriate to question the often-assumed linear and negative association of politics perceptions with important work outcomes (Ferris \& Hochwarter, in press; Hochwarter, 2003b).

In response, we developed a series of three studies (which include a total of 5 samples) to explore nonlinear politics perceptions-work outcomes relationships. More specifically, Study 1 was designed to examine the nonlinear relationship between politics perceptions and job satisfaction (i.e., in Sample 1), and we sought a literal replication of those results in a second sample. Study 2 assessed the nonlinear relationship between politics perceptions and job tension (i.e., in Sample 3), and replication was sought again (i.e., Sample 4). Finally, in a single-sample investigation, Study 3 examined moderator effects on nonlinear politics perceptions-work outcome relationships. In particular, we investigated the role of perceived work resources (Hochwarter, Laird, \& Brouer, 2008; Hochwarter, Perrewé, Meurs, \& Kacmar, 2007) on the nonlinear relationship between politics perceptions and job tension. Positing nonlinear politics perceptions-work outcome relational forms is consistent with Warr's (1987) Vitamin Model and the Activation Theory of Stress (Gardner \& Cummings, 1988), both of which are subsequently discussed in detail.

Job satisfaction and tension were chosen as outcomes in this research for several reasons. First, perceived politics often elicit significant emotional reactions, which produce immediate effects on the level of satisfaction and tension individuals experience on the job (Ferris et al., 2002; Locke, 1976). Ferris et al. (1989) noted that politics perceptions influence outcomes, including job satisfaction and anxiety, because of the threatening and aversive work environments they often provoke. Witt, Andrews, and Kacmar (2000) reported that the unfair reward allocations often associated with political environments cause discontent (e.g., lower satisfaction and higher anxiety), and pertinent reviews of the literature have documented these effects (Kacmar \& Baron, 1999; Miller, Rutherford, \& Kolodinsky, 2008). Second, job 
satisfaction and tension represent the most frequently studied attitudinal outcomes of politics perceptions (Ferris et al., 2002). Consequently, investigating alternative relational forms with outcomes possessing theoretical validation and empirical documentation will extend the existing research base.

Finally, this three-study, five-sample investigation represents the multistudy package recommended by Tsui (1999) who forecasted imminent research expectations in the organizational sciences. In the present investigation, we test for a nonlinear relationship of politics perceptions with one important outcomes variable, seek replication, then test for the nonlinear form with a second criterion variable, and also seek convergence. In the final step (i.e., Study 3), we attempt to address the issue of whether the nonlinear relationship of politics perceptions and work outcomes is unrestricted (i.e., invariant across all conditions) or constrained by the presence of a moderator variable.

\section{Nonlinear Politics Perceptions Relational Forms}

At first glance, the arguments depicted in the present investigation may be nothing short of heresy in the eyes of traditional politics researchers. Until recently, the literature has been so tightly coupled with negative aspects of the organizational experience that the mere suggestion of organizational politics (or the perceptions thereof) as elevating job satisfaction and reducing job tension would have been viewed as conceptually and empirically improbable. However, recent discussions have called for the reconsideration of politics perceptions-work outcomes relational forms (Hochwarter \& Treadway, 2003).

For example, Harris and Kacmar (2003: 96) acknowledged "as perceptions of politics increase, so do anxiety levels and intentions to turnover. However, it is possible that, at some point, an increase in perceptions of politics no longer continues to increase one's level of anxiety." Harris and Kacmar further posited that the "shock" of others' influence behavior may, in fact, level off over time, prompting a nonlinear relationship between politics perceptions and work outcomes. Finally, Ferris et al. (2006) argued that individuals would struggle in settings deficient of politics because of an inability to gather behavioral cues.

Conversely, high levels of perceived politics would cause individuals to spend excessive amounts of time questioning others' motives, which would leave less time for participation in actual work behavior, thus resulting in a nonlinear relationship. Hochwarter (2003b) confirmed that exceedingly low and high levels of political behavior (i.e., U-shaped form) were associated with heightened job tension. Although political behavior and politics perceptions may be considered conceptually unique (albeit empirically and theoretically related in prior research; Higgins, Judge, \& Ferris, 2003), this finding illustrates the importance of considering influence behavior (i.e., perceptions and reactions) as a nonlinear phenomenon (Ferris et al., 2006).

In sum, proponents of testing nonlinear politics perceptions-work outcomes relationships have argued as follows: (a) Politics at low levels may exhibit harmful effects; (b) expansion from low to moderate levels may be beneficial; and (c) increases from moderate to excessive levels are detrimental or cause a leveling-off effect. Despite the validity of these arguments, substantive research has yet to verify their legitimacy in organizational settings. Our objective in this research is to do so. However, to do so effectively, it is important to heed Warr, 
who noted that "it is essential to distinguish between separate segments of a jobcharacteristic range; the nature of associations with employee reactions can differ between low, medium, and high levels of a job feature" (1990: 293).

\section{Situations Where Politics Perceptions Are Low}

Considerable research has documented politics perceptions as one of the many demands that individuals experience while at work (Cropanzano \& Li, 2006; Halbesleben \& Wheeler, 2006), hence legitimizing its status as a workplace stressor (Cropanzano, Howes, Grandey, \& Toth, 1997; Ferris, Frink, Galang, Zhou, Kacmar, \& Howard, 1996). Given this conceptualization, both Activation Theory (Janssen, 2001) and the Vitamin Model (Warr, 1987) are particularly useful in describing when low levels of a job demand are detrimental to attitudes and behaviors. More specifically, Activation Theory maintains that a demand at low levels is initially harmful because of its inability to generate arousal (e.g., motivation; Scott, 1966). With respect to politics perceptions as an external demand, Activation Theory argues that lesser social wrangling in the immediate work environment (i.e., low politics perceptions) is disadvantageous because one's level of activation needed to engage in the workplace is largely deficient (Gardner, 1986; Singh, 1998).

According to Gardner and Cummings, "high and low activation levels impair the ability to process information" and "job stress occurs whenever job-related stimuli cause a job holder's experienced activation level to deviate substantially from one's characteristic level of activation" (1988: 89). As noted in prior research (Buchanan \& Badham, 1999; Gandz \& Murray, 1980; Mintzberg, 1983), employees expect some level of politics to occur, and when the work situation is devoid of such activity, few contextual cues exist to guide behavior, causing distress (Dawis \& Lofquist, 1984; Ferris \& Hochwarter, in press).

Furthermore, when political activity is limited, there are few referents for comparison. Thus, with no behaviors to model (i.e., either favorable or unfavorable), individuals are left to their own discretion to "construe reality" (Neisser, 1976), which often leads to faulty decisions and objectionable outcomes (Weick, 1995). Evidence for such an effect was documented by Hochwarter, Perrewé, Hall, and Ferris (2005), who found that fewer accountability demands (i.e., an external stressor much like politics perceptions) were coupled with less than optimal levels of job tension.

Nonlinear relationships between job features and well-being represents the core assumption of Warr's (1987, 1990) Vitamin Model. Accordingly, the effect of a particular job demand on work well-being is analogous to the influence that vitamins have on the human body. That is, a vitamin deficiency gives rise to physiological impairment at low intake levels. However, as intake levels increase, well-being is improved up to a point, and once an optimal level is exceeded, benefits either taper off or begin to decline (Baltes Bauer, Bajdo, \& Parker, 2002). The nonlinear job demands-well-being relationship posited in this model has been corroborated in prior research (Warr, 1990). For example, De Jonge and Schaufeli (1998) found that job tension decreased as demands increased from low to moderate levels, whereas Warr (1990) reported that both work anxiety and decision latitude had nonlinear effects on job satisfaction. 
Karasek described job demands as "psychological stressors involved in accomplishing the work load" (1979: 291), which is a definition consistent with recent conceptualizations of politics perceptions (Halbesleben, Osburn, \& Mumford, 2006). Moreover, politics perceptions have been associated with work outcomes at a level comparable with other adverse job characteristics (De Jonge \& Schaufeli, 1998), again legitimizing its status as a job demand (Cropanzano \& $\mathrm{Li}, 2006$ ). Hence, we expect politics perceptions to operate, as would other demands, within the frameworks of both Activation and Vitamin Model theories. Specifically, job satisfaction will be low and job tension will be high when politics perceptions are low.

\section{Situations Where Politics Perceptions Are Moderate}

Activation and Vitamin Theories are consistent in their treatment of moderate job demand levels. Specifically, job expectations are posited to have their most beneficial effect as they increase from low to intermediate levels (Gardner, 1986; Xie \& Johns, 1995). More than 30 years ago, Chung and Ross reported, "Most skilled workers then will find their optimal levels of job satisfaction and productivity when their jobs are moderately enlarged and enriched" (1977: 119). According to Warr, "Humans have acquired the potential to cope with a wide span of environmental conditions, with problems of adaptation occurring only at relatively extreme levels" (1987: 12). Selye (1976) noted that moderate amounts of a job demand are preferable because it is at this level that sensitivity motivates individuals to excel. Finally, our arguments are consistent with person-environment fit studies of stress (Edwards \& Cooper, 1990), which have maintained that well-being reflects the equivalence or discrepancy between preferred and reported levels of environmental stressors (Warr, 1990).

In terms of activation, research has suggested that external stimuli perceived as mildly threatening (e.g., moderate levels of politics perceptions) are the most readily identifiable and salient (Christianson, 1992). Politics that are evident, yet tolerable, attract observers' attention by indicating that external stressors and threats exist and should be evaluated for potential harm (Salancik \& Pfeffer, 1978). Additionally, the level of information offered by contextual cues is sufficient for the observer to develop affective reactions to the behavior of others, without exhausting attentiveness needed to simultaneously participate in task and social domains. Finally, individuals are able to determine the motives and merits of others, develop a more informed view of job requirements, and attend to specific task obligations when politics are moderate (Ferris et al., 2002). Therefore, it is at this level of politics perceptions that we expect job satisfaction and job tension to reach its least detrimental levels.

\section{Situations Where Politics Perceptions Are High}

Activation and Vitamin Models further maintain that increases in job demands from moderate to high levels will produce undesirable outcomes (Champoux, 1992). In support, Warr (1994) reported that heightened demands increase cognitive overload, subsequently prompting coping failures, hindering decision making, and facilitating a loss of control. Moreover, 
the Vitamin Model (Warr, 1987) acknowledges that excessive job demands promote attention switching, which leads to diminished concentration and achievement in both work and nonwork contexts. In terms of the present research, those confronting high levels of politics may be forced to focus their attention on others' self-serving tactics at the expense of behaviors relevant to their own job performance (e.g., input from coworkers, suggestions from clients). Attention swapping, which serves as a distraction, taps finite cognitive and psychological resources (Bakker, Demerouti, \& Euwema, 2005). Treadway, Ferris, Hochwarter, Perrewé, Witt, and Goodman (2005b) argued that highly political settings deplete individuals of the resources needed to maintain or improve one's status in the organization.

Considerable evidence supports the detrimental effects of excessive levels of politics perceptions on job satisfaction and job tension. In fact, the contention that politics perceptions adversely affects these outcomes is perhaps the most well-established finding reported in the existing social influence literature (Ferris et al., 2002). As examples, Rosen, Levy, and Hall (2006) found a heightened politics perceptions-job satisfaction relationship, whereas Harris and Kacmar (2005) reported comparable adverse effects on job tension. Although these studies examined linear relational forms exclusively, their findings are uniquely supportive of one section of both Vitamin and Activation models of stress-namely, its far right segment of the U-shaped form. Based on our discussion of the range of politics perceptions, we offer the following testable hypotheses:

Hypothesis 1a: Politics perceptions will demonstrate an inverted U-shaped relationship with job satisfaction. Specifically, higher and lower levels of politics perceptions will be associated with the lowest levels of job satisfaction, and moderate levels of politics perceptions will be associated with the highest level of job satisfaction.

Hypothesis 1b: Politics perceptions will demonstrate a U-shaped relationship with job tension. Specifically, higher and lower levels of politics perceptions will be associated with the highest levels of job tension, and moderate levels of politics perceptions will be associated with the lowest level of job tension.

\section{Moderator Effects on Nonlinear Politics Perceptions-Work Outcomes Relationships}

Demonstrated nonlinearity does not rule out the possibility for more complex relational forms to emerge. In fact, Ferris et al. (2006) acknowledged that examining moderators of nonlinear relationships can provide an additional level of precision virtually ignored by most researchers. In Activation Theory and Vitamin Model domains, research has recognized that nonlinear relational forms may not be invariant across individuals and environments (Janssen, 2001). For example, Xie and Johns (1995) found that demand-ability fit moderated the nonlinear job complexity-exhaustion relationship, whereas Brockner, Grover, Reed, and DeWitt (1992) reported that the curvilinear layoff job insecurity-work effort relationship was moderated by the economic need to work. Finally, Champoux (1992) examined the moderating effect of work context satisfaction on nonlinear job scope-affective outcomes relationships. 
Simultaneously building on these prior studies and expanding on our earlier nonlinear conceptualization, we examine the moderating potential of perceived resources (e.g., energy, equipment/personnel, support, respite, pacing, autonomy; Hochwarter et al., 2008) on the form and magnitude of the politics perceptions-job tension relationship. Evidence for examining this moderator can be found in linear and nonlinear examinations of job stress. In terms of linear applications, Hochwarter et al. (2007) found that perceived resources moderated the relationship between work-induced guilt and both job and life satisfaction. Other research (Hochwarter et al., 2008) reported that resource availability influenced hurricane-induced job stress-strain relations. Warr (1994) identified three individual difference moderators of nonlinear job demands-outcomes relationships, one of which was ability. According to Hobfoll and Freedy (1993), ability represents an important resource with considerable potential to neutralize adverse stress reactions.

In the present research, we contend that one's ability to secure resources will moderate the nonlinear relationship between politics perceptions and job tension. More specifically, we contend that low and high levels of politics perceptions will be associated with higher levels of job tension (i.e., U-shaped relationship) for those with fewer resources. Again, our arguments are consistent with those purported by Activation and Vitamin models of stress. For example, at low levels of activation, there is both insufficient energy to seek out ways to most effectively manage one's existing resource base (Gaudine \& Thorne, 2001) and limited motivation to pursue new opportunities for growth (Isen, Daubman, \& Nowicki, 1987).

Logically, an environment with few job demands (i.e., low levels of politics perceptions) should facilitate the accrual of new or better resources. Specifically, Hobfoll proposed that "people must invest resources in order to protect against resource loss, recover from losses, and gain resources" (2001: 349). However, doing so requires individuals to tap into their reserve. Hobfoll (2001) noted that those with fewer resources are less capable of resource gain, especially in settings where demands are limited, because of the defensive posture often undertaken to maintain, rather than augment, their existing store. Westman and Etzion (2002) contended that those with fewer resources are likely frustrated by the inability to experience resource gain spirals that occur following investments. Hence, we expect job tension to be high for those with fewer resources when politics perceptions are low.

We are not advocating that moderate levels of perceived politics are optimal for those with fewer resources. Instead, we contend that this situation is simply "less unfavorable" than when politics perceptions are either high or low. At moderate levels, politics perceptions are threatening enough to discourage the unproductive pursuit of additional resources, yet not too foreboding to mandate the rapid resource depletion associated with demand-generated coping (Aspinwall \& Taylor, 1997). Hence, resources would remain largely intact. Research has indicated that a state of "resource homeostasis" is conducive to positive wellbeing (Shinn \& Rapkin, 2000). In support of this perspective, Cropanzano and Li noted that others' political behavior “may or may not overwhelm one's coping resources" (2006: 156).

Finally, those with fewer resources are expected to experience heightened job tension when politics perceptions are excessively high. At high levels of perceived politics, individuals are aroused to the point of overload, leading to cognitive impairment (Gardner \& Cummings, 1988). One such impairment, tunneling, causes individuals to disregard potentially important stimuli because of an overexaggerated emphasis on one aspect of the contextual environment at the 
expense of others considered equally important (Baumann, Sniezek, \& Buerkle, 2001). This impediment is expected to be particularly taxing on those with fewer coping resources (Cohen \& Willis, 1985). Hence, an individual with an already depleted store of resources will likely experience the downward loss spirals that occur when demands exceed buffering capabilities. In support, Hobfoll and Freedy (1993) reported that job demands threaten one's resources, and over time, prolonged exposure will trigger strain. Based on this discussion, we hypothesize the following:

Hypothesis 2: For those with low levels of perceived resources, politics perceptions will demonstrate a U-shaped relationship with job tension. Specifically, higher and lower levels of politics perceptions will be associated with the highest levels of job tension, and moderate levels of politics perceptions will be associated with the lowest level of job tension.

For those with sufficient resources, politics are posited to demonstrate little influence on job tension as they increase from low to high levels. Resource management acuity (e.g., building, maintaining, using; Hobfoll, 2001) has long been associated with effective coping (Hobfoll, 1989). Latack and Havlovic argued that coping "entails constantly changing cognitive and behavioral efforts to manage the internal and external demands of transactions that tax or exceed a person's resources" (1992: 483). In support, Ito and Brotheridge (2003) found that an individual's resource level (i.e., positive orientation, working harder, and seeking advice/assistance) was positively associated with active coping.

Brouer, Ferris, Hochwarter, Laird, and Gilmore (2006) found that political skill, conceptualized as a personal resource, influenced the relationship between politics perceptions and depressive symptoms. Namely, those with fewer resources experienced the most depressive symptoms. Ferris et al. (1996) corroborated a neutralizing influence of control on politics perceptions-work anxiety relationship. Finally, Halbesleben and Wheeler (2006) found that resources, in the form of social support, moderated politics perceptions-burnout relationships. Based on the strength of these findings as well as the theoretical justification confirmed in the prior research, we hypothesize the following:

Hypothesis 3: For those with high levels of perceived resources, politics perceptions will have little effect on job tension as they increase from low to high levels.

\section{Study 1: Methods}

\section{Participants and Procedures}

Sample 1. The human resources department of a large university distributed 502 surveys to clerical and administrative personnel. We received 309 completed surveys (i.e., response rate of $61 \%$ ) through intraoffice mail. Respondents averaged 43 years of age, 12 years of organizational tenure, and 6 years of position tenure. The majority of the sample was female (i.e., 74\%). Archival data indicated no response bias with respect to age, gender, or organizational tenure. 
Sample 2. All 147 employees of a state agency received surveys through intraoffice mail. Respondents returned completed instruments to a central location. We gathered 105 (i.e., response rate of $71 \%$ ) completed surveys. Respondents averaged 37 years of age, 8 years of organizational tenure, and 4 years of position tenure. The sample consisted of 63 women (i.e., 62\%). Archival data indicated no response bias effect with respect to age or gender (the organization did not maintain tenure data).

\section{Measures}

Positive and negative affect. Affective disposition was measured using the 20-item Positive and Negative Affect Scale (PANAS, Watson, Clark \& Tellegen, 1988). Participants were asked to indicate how they felt "in general, that is on the average" by responding to words such as "distressed", "jittery," and "nervous" for negative affect (NA) and "interested," "enthusiastic," and "attentive" for positive affect (PA). Possible responses ranged from very slightly or not at all (1) to extremely (5). Internal consistency reliability estimates for NA ( $\alpha=.82$ and .89 for Samples 1 and 2) and PA ( $\alpha=.84$ and .84 for Samples 1 and 2) were adequate.

Politics perceptions. Perceptions of organizational politics were measured using a 6-item scale developed by Hochwarter (2003a). "At work, there is a lot of self-serving behavior going on" represents a scale item. A 5-point response format was used ranging from strongly disagree (1) to strongly agree (5). Reliability estimates for the scale $(\alpha=.87$ and .88 for Samples 1 and 2) were adequate.

Job satisfaction. Consistent with recent research (Judge, Ilies, \& Scott, 2006), job satisfaction was measured using Brayfield and Rothe's (1951) 5-item index. "Each day of work seems like it will never end" (reversed coded) represents a scale item. A 5-point response format was used ranging from strongly disagree (1) to strongly agree (5). Reliability estimates for the scale $(\alpha=.82$ and .86 for Samples 1 and 2$)$ were adequate.

\section{Data Analysis}

Hierarchical regression analyses were conducted to assess the linear and nonlinear relationships between politics perceptions and job satisfaction (Cohen, Cohen, West, \& Aiken, 2003). In the first step, demographic variables (i.e., age, gender, organization tenure, and position tenure) and affective disposition were entered. Effects of these demographic factors have been documented in prior research. For example, Nelson, Quick, and Hitt (1989) reported that females reported more job stress from politics perceptions than males, whereas Hochwarter, Ferris, Perrewé, Witt, and Kiewitz (2001) found that age possessed complex relationships with job satisfaction. Researchers (Burke, Brief, \& George, 1993; Podsakoff, MacKenzie, Lee, \& Podsakoff, 2003) contend that affectivity can affect self-report perceptions of organizational phenomena, especially those that are potentially anxiety provoking 
(Perrewé \& Spector, 2002). Hence, taking into account their potential influence is warranted in the present research. The linear politics perceptions term was entered in the second step, followed by the nonlinear politics perceptions term. As a final check, the politics perceptions cubed term was entered in the final step (i.e., a significant cubed term would indicate an $\mathrm{S}$-shaped relational form). Significance is demonstrated if the squared politics perceptions term explains incremental criterion variance beyond that of the linear term (Stimson, Carmines, \& Zeller, 1981).

\section{Study 1: Results}

In Table 1, we report the descriptive statistics and correlations of all variables in Study 1, Samples 1 and 2. In each sample, constructs expected to correlate (e.g., NA, PA, politics perceptions, and job satisfaction) did so in form and magnitude, consistent with results shown in prior research. For example, NA and PA demonstrated associations with job satisfaction at a level comparable with recent meta-analytic work (Thoresen, Kaplan, Barsky, Warren, \& de Chermont, 2003). It is noteworthy that the linear politics perceptions-job satisfaction zero-order correlations in both samples were significant and negative, with the range of association largely reflective of what has been reported in the literature to date (e.g., Ferris et al., 2002).

Hierarchical regression results presented in Table 2 indicate that the linear politics perceptions term inversely predicted job satisfaction $(\beta=-.59, p<.01)$. Furthermore, the squared politics perceptions term was significant in both samples $(\beta=-.13, p<.05$ and $\beta=$ $-.08, p<.05$, respectively), explaining $3 \%$ to $4 \%$ of criterion variance. The negative betas in this step indicate a nonlinear association best represented by an inverted-U form. The politics perceptions cubed term in the next step was not significant in either Sample 1 ( $\beta=-.02$, $\mathrm{ns})$ or Sample 2 ( $\beta=.10, \mathrm{~ns})$, further supporting an inverted- $U$ shape as the most representative politics perception-job satisfaction relational form.

As outlined by Cohen et al. (2003) and Aiken and West (1991), we plotted the nonlinear relationship by first identifying points at high and low levels of politics perceptions and then calculating points along the continuum. Figures 1 and 2 illustrate the nonlinear relationship of politics perceptions and job satisfaction for Samples 1 and 2. Specifically, job satisfaction was lowest when politics perceptions were both high and low.

\section{Study 2: Methods}

\section{Participants and Procedures}

Sample 3. Employees of a state agency in the Southeastern United States, in groups of approximately 20 to 30 (average $=28$ ), completed surveys following development exercises. Participants completed the survey, placed it in an envelope, and returned it directly to the researchers. The content of the survey was not addressed during these sessions. The group was made aware that the survey was to be used for research purposes exclusively. Of the 228 surveys distributed during these sessions, 217 were determined useable (e.g., incomplete 
Table 1

Means, Standard Deviations, and Intercorrelations

Among Study Variables (Samples 1-4)

\begin{tabular}{|c|c|c|c|c|c|c|c|c|c|}
\hline Variable & Mean & $\begin{array}{l}\text { Standard } \\
\text { Deviation }\end{array}$ & 1 & 2 & 3 & 4 & 5 & 6 & 7 \\
\hline \multicolumn{10}{|l|}{ Sample 1} \\
\hline 1. Age & 43.11 & 6.44 & - & & & & & & \\
\hline 2. Gender & - & - & .04 & - & & & & & \\
\hline 3. Organization tenure & 11.58 & 5.98 & $.35^{*}$ & .07 & - & & & & \\
\hline 4. Position tenure & 5.71 & 4.04 & .02 & .07 & $.14^{*}$ & - & & & \\
\hline 5. NA & 1.62 & 0.55 & -.02 & -.08 & .04 & -.08 & - & & \\
\hline 6. PA & 3.66 & 0.68 & .04 & .05 & -.01 & -.02 & $-.31 *$ & - & \\
\hline 7. Politics perception & 3.24 & 0.71 & .01 & -.02 & .02 & $-.17 *$ & $.44 *$ & $-.32 *$ & - \\
\hline 8. Job satisfaction & 3.42 & 0.93 & .08 & .09 & .06 & .03 & $-.41 *$ & $.35^{*}$ & $-.36 *$ \\
\hline \multicolumn{10}{|l|}{ Sample 2} \\
\hline 1. Age & 36.46 & 16.97 & - & & & & & & \\
\hline 2. Gender & - & - & $-.30 *$ & - & & & & & \\
\hline 3. Organization tenure & 8.09 & 7.70 & $.51 *$ & -.16 & - & & & & \\
\hline 4. Position tenure & 3.39 & 3.27 & $.41 *$ & -.04 & $.59 *$ & - & & & \\
\hline 5. NA & 1.60 & 0.72 & -.11 & -.09 & -.06 & -.11 & - & & \\
\hline 6. PA & 3.56 & 0.74 & -.16 & $.18^{*}$ & .03 & -.12 & $-.20 *$ & - & \\
\hline 7. Politics perception & 3.20 & 0.81 & -.09 & .06 & -.10 & -.08 & $.26 *$ & $-.17 *$ & - \\
\hline 8. Job satisfaction & 3.04 & 0.43 & -.02 & -.03 & -.07 & -.03 & $-.35^{*}$ & $.32 *$ & $-.25 *$ \\
\hline \multicolumn{10}{|l|}{ Sample 3} \\
\hline 1. Age & 46.34 & 9.93 & - & & & & & & \\
\hline 2. Gender & - & - & $-.21 *$ & - & & & & & \\
\hline 3. Organization tenure & 10.57 & 10.08 & $.42 *$ & $-.30 *$ & - & & & & \\
\hline 4. Position tenure & 6.73 & 6.23 & $.40 *$ & $-.28 *$ & $.49 *$ & - & & & \\
\hline 5. NA & 1.77 & 0.78 & $-.25 *$ & $.15^{*}$ & $-.16^{*}$ & $-.14 *$ & - & & \\
\hline 6. PA & 3.81 & 0.70 & -.05 & .04 & .10 & -.01 & .04 & - & \\
\hline 7. Politics perception & 2.67 & 0.92 & $-.16^{*}$ & -.04 & .01 & .04 & $.19 *$ & .03 & - \\
\hline 8. Job tension & 2.61 & 0.76 & $.04 *$ & -.07 & $.16^{*}$ & $.16^{*}$ & $.20 *$ & $-.24 *$ & $.36 *$ \\
\hline \multicolumn{10}{|l|}{ Sample 4} \\
\hline 1. Age & 44.69 & 11.04 & - & & & & & & \\
\hline 2. Gender & - & - & .02 & - & & & & & \\
\hline 3. Organization tenure & 10.96 & 8.90 & $.58 *$ & .00 & - & & & & \\
\hline 4. Position tenure & 6.19 & 6.12 & $.46^{*}$ & -.05 & $.50 *$ & - & & & \\
\hline 5. NA & 1.60 & 0.59 & -.12 & .01 & .04 & .04 & - & & \\
\hline 6. PA & 3.66 & 0.79 & -.03 & .03 & .00 & -.01 & -.12 & - & \\
\hline 7. Politics perception & 2.70 & 0.84 & -.05 & -.07 & -.03 & -.11 & .15 & .07 & - \\
\hline 8. Job tension & 2.73 & 0.76 & .05 & $-.14 *$ & .06 & $.30 *$ & $.20 *$ & .01 & $.25 *$ \\
\hline
\end{tabular}

Note: NA, negative affect; PA, positive affect.

$* p<.05$.

sections, unreadable responses). The sample consisted of 149 women (69\%), who averaged 46 years of age. Job titles were exclusively white-collar and professional in nature. Archival data provided by human resources indicated no sample population bias with respect to age and gender. 
Table 2

Regression Analyses (Studies 1-4)

\begin{tabular}{|c|c|c|c|c|}
\hline \multirow[b]{2}{*}{ Step } & \multicolumn{2}{|c|}{ Study 1} & \multicolumn{2}{|c|}{ Study 2} \\
\hline & $\begin{array}{c}\text { Sample } 1 \\
\text { Job } \\
\text { Satisfaction } \\
\beta\end{array}$ & $\begin{array}{c}\text { Sample } 2 \\
\text { Job } \\
\text { Satisfaction } \\
\beta\end{array}$ & $\begin{array}{c}\text { Sample } 3 \\
\text { Job } \\
\text { Tension } \\
\beta\end{array}$ & $\begin{array}{c}\text { Sample } 4 \\
\text { Job } \\
\text { Tension } \\
\beta\end{array}$ \\
\hline \multicolumn{5}{|l|}{ Step 1} \\
\hline Age & .01 & .01 & -.01 & -.01 \\
\hline Gender & .10 & -.09 & -.04 & -.12 \\
\hline Organization tenure & -.01 & -.01 & $.02 * *$ & -.01 \\
\hline Position tenure & .01 & .01 & .01 & $.05 * *$ \\
\hline NA & $-.57 * *$ & $-.15 * *$ & $.14 * *$ & $.12 *$ \\
\hline PA & $.33 *$ & $.14 * *$ & $-.10 * *$ & .03 \\
\hline$\Delta R^{2}$ & .24 & .22 & .17 & .18 \\
\hline \multicolumn{5}{|l|}{ Step 2: } \\
\hline Politics perception & $-.59 * *$ & -.06 & $.36^{* *}$ & $.17 *$ \\
\hline$\Delta R^{2}$ & $.15^{* *}$ & .01 & $.17 * *$ & $.03 *$ \\
\hline \multicolumn{5}{|l|}{ Step 3} \\
\hline Politics perception ${ }^{2}$ & $-.13 *$ & $-.08 *$ & $.11 * *$ & $.14 *$ \\
\hline$\Delta R^{2}$ & $.03 *$ & $.03 *$ & $.02 * *$ & $.03 *$ \\
\hline \multicolumn{5}{|l|}{ Step 4} \\
\hline Politics perception ${ }^{3}$ & -.02 & .10 & -.01 & .08 \\
\hline$\Delta R^{2}$ & .00 & .00 & .00 & .01 \\
\hline
\end{tabular}

Note: NA, negative affect; PA, positive affect.

$* p<.05$.

$* * p<.01$.

Figure 1

The Nonlinear Effects of Politics Perceptions on Job Satisfaction (Sample 1)

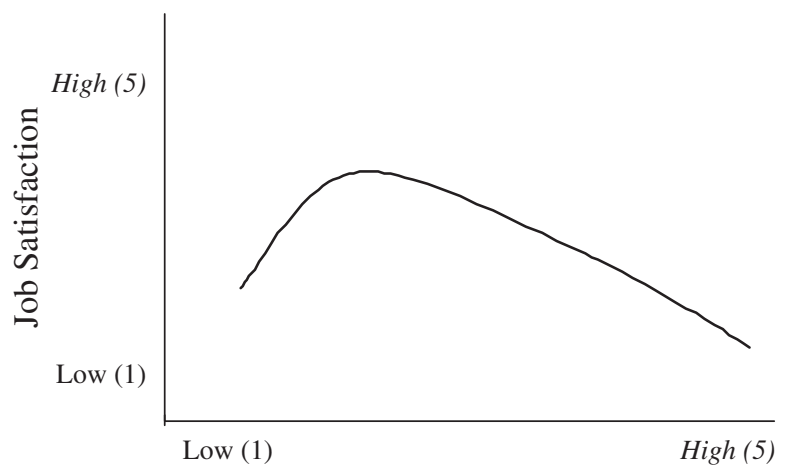

Politics Perceptions 
Figure 2

The Nonlinear Effects of Politics Perceptions on Job Satisfaction (Sample 2)

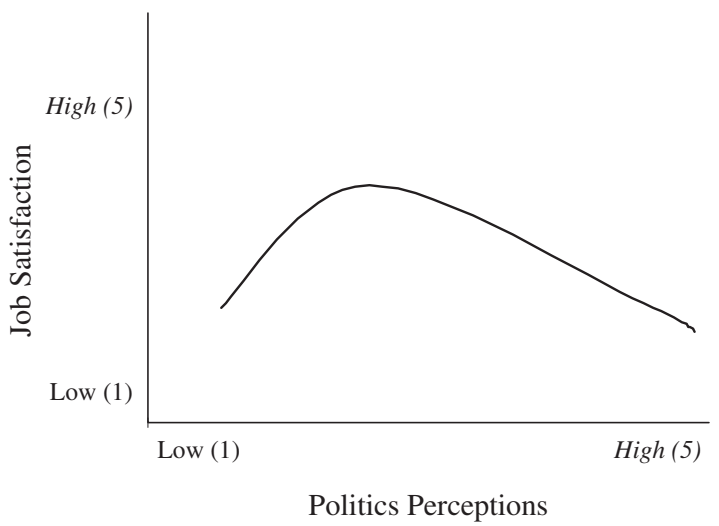

Sample 4. As part of an applied research project, all 199 members of a financial services organization in the Southern United States received surveys in their company mailbox. The organization was a branch operation of a large, multinational firm. Leaders at the branch allowed employees work time to complete the survey, the results of which were presented to management in report form 6 months after the data collection. Employees were prompted 1 week after the initial survey distribution. Respondents were provided a stamped return envelope addressed directly to the researchers. A total of 126 surveys were returned for a response rate of $63 \%$. The sample consisted of 71 women $(56 \%)$ and averaged 45 years of age. Archival data provided by human resources indicated no population-sample differences with respect to gender. However, those who returned surveys were slightly older than the population (44.69 vs. 43.10).

\section{Measures}

Positive and negative affect. Affective disposition was measured using the 20-item PANAS (Watson et al., 1988). Internal consistency reliability estimates for NA $(\alpha=.88$ and .84 for Samples 3 and 4$)$ and PA ( $\alpha=.90$ and .82 for Samples 3 and 4) were adequate.

Politics perceptions. Consistent with Study 1, perceptions of organizational politics were measured using Hochwarter's (2003a) scale. Reliability estimates for the scale $(\alpha=.81$ and .80 for Samples 3 and 4) were adequate.

Job tension. We measured job tension $(\alpha=.87)$ with a 7-item measure developed by House and Rizzo (1972). Representative items included "My job tends to directly affect my health" and "I work under a great deal of tension." Possible responses ranged from disagree 
Figure 3

The Nonlinear Effects of Politics Perceptions on Job Tension (Sample 3)

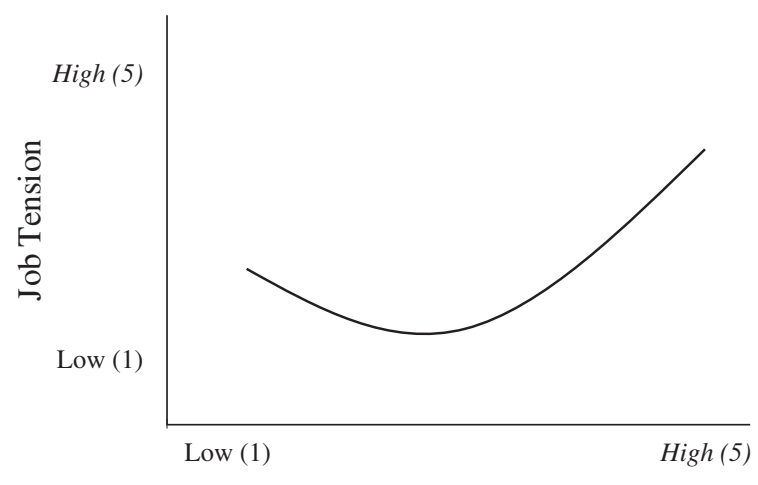

Politics Perceptions

strongly (1) to agree strongly (7). Reliability estimates for the scale $(\alpha=.89$ and .79 for Samples 3 and 4) were adequate.

\section{Study 2: Results}

Tables 1 and 2 contain descriptive statistics and regression results for Study 2, Samples 3 and 4. The linear politics perceptions term predicted job tension in Samples 1 ( $\beta=.36, p<$ $.01)$ and $2(\beta=.17, p<.05)$. The squared politics perceptions term was significant in both samples $(\beta=.11, p<.01$ and $\beta=.14, p<.05$, respectively), explaining $2 \%$ to $3 \%$ of job tension criterion variance. The positive betas in this step indicate a nonlinear association best represented by a U-shaped form. The politics perceptions cubed term in the final step was not significant in either Sample $3(\beta=-.01$, ns) or Sample $4(\beta=.08$, ns), further supporting a $U$ shape. These forms, which indicate that job tension is lowest when politics is both low and high, are illustrated in Figures 3 and 4.

\section{Study 3: Methods}

\section{Participants and Procedures}

Sample 5. We distributed 297 surveys to employees of a public works organization as part of an applied research project. Employees were provided a stamped return envelop addressed to the researchers at their university location. Management allowed employees to complete the survey on company time. We received a total of 198 surveys; however, 2 were deemed unusable. Hence, the final response rate was $67 \%$. The majority of the sample was female (i.e., 74\%), and respondents averaged 41 years of age and 7 years of tenure. Archive 


\section{Figure 4}

The Nonlinear Effects of Politics Perceptions on Job Tension (Sample 4)

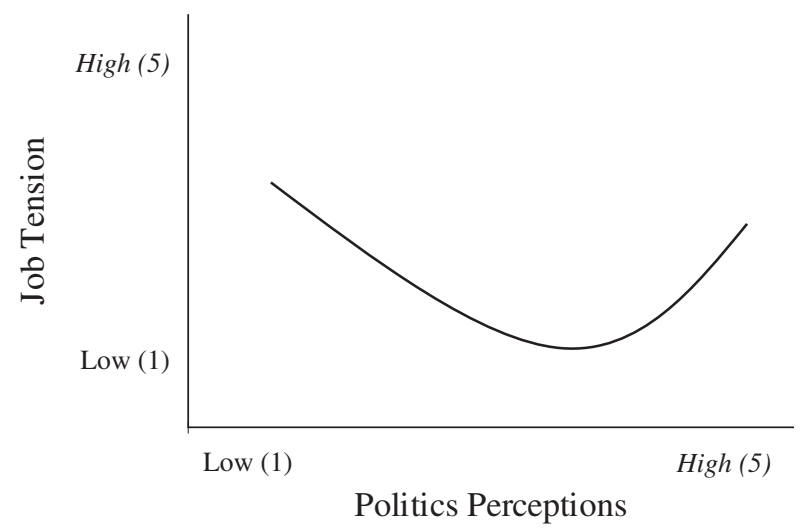

indicated no sample population differences with respect to age and gender (tenure information was not provided).

\section{Measures}

Positive and negative affect. Affective disposition was measured using the 20-item PANAS (Watson et al., 1988). Internal consistency reliability estimates for NA $(\alpha=.80)$ and PA $(\alpha=.92)$ were adequate.

Politics perceptions. Perceptions of organizational politics were measured using Hochwarter's (2003a) scale. The reliability estimate for the scale $(\alpha=.86)$ was adequate.

Perceived resources. Consistent with prior research (Hochwarter et al., 2007; Hochwarter et al., 2008), we measured perceived resources using a 6-item scale. Representative items included "When work is stressful, I am able to conserve my energy" and "I have enough equipment and personnel at my disposal to fill in for me at work." Possible responses ranged from disagree strongly (1) to agree strongly (5). The reliability estimate for the scale $(\alpha=$ .76) was adequate.

Job tension. We measured job tension using House and Rizzo's (1972) scale. The reliability estimate for the scale $(\alpha=.80)$ was adequate.

\section{Data Analyses}

Hierarchical moderated polynomial regression analyses were conducted to test the effects of the hypothesized quadratic politics perceptions by resource management accountability 
interaction term on job tension. To test the interaction between perceptions $(\boldsymbol{X})$ and perceived resources $(\boldsymbol{Z})$ on job tension $(\boldsymbol{Y})$, the following equation was used (Aiken \& West, 1991; Cohen et al., 2003):

$$
\boldsymbol{Y}=b_{1} \boldsymbol{X}+b_{2} \boldsymbol{X}^{2}+b_{3} \boldsymbol{Z}+b_{4} \boldsymbol{X} \boldsymbol{Z}+b_{5} \boldsymbol{X}^{2} \boldsymbol{Z}+c_{0}
$$

The regression analyses consisted of six consecutive steps. In the first step, sociodemographic variables and affectivity were entered to control for their potential confounding effects. In Steps 2 and 3, the perceived politics linear $(\boldsymbol{X})$ and nonlinear terms $\left(\boldsymbol{X}^{2}\right)$ were entered. In the fourth step, the perceived resources term $(\boldsymbol{Z})$ was entered followed by the linear interaction between politics perceptions and perceived resources $(\boldsymbol{X} \boldsymbol{Z})$. In the final step, the nonlinear politics perceptions by perceived resource term $\left(\boldsymbol{X}^{2} \boldsymbol{Z}\right)$ was entered. The objective of this step was to determine whether the nonlinear relationship between politics perceptions and job tension was consistent across levels of perceived resources.

\section{Study 3: Results}

Descriptive statistics and polynomial regression results are provided in Tables 3 and 4 . As shown, NA $(\beta=.18, p<.01)$, perceived resources $(\beta=-.14, p<.05)$, and the linear politics perception terms $(\beta=.31, p<.01)$ predicted job tension. In the final step, the linear perceived resource by nonlinear politics perception term explained incremental job satisfaction criterion variance $\left(\beta=-.20, \Delta R^{2}=.04, p<.01\right)$.

To further investigate the significant relationship between the linear perceived resources and nonlinear politics perception term on job tension, the sample was partitioned into highand low-resource management subgroups. Consistent with previous research (Cohen et al., 2003), scores at one standard deviation below and one standard deviation above the mean were used to categorize high- and low-perceived resources groups. Job tension was regressed on linear and nonlinear politics perceptions terms for each group. In Step 1, the sociodemographic variables and affectivity were again included, followed by the linear politics perceptions term and nonlinear politics perception term in the second and third steps, respectively (complete tables are available from the authors).

For the low-perceived resources group, the linear politics perceptions term was not significant $(\beta=.24, \mathrm{~ns})$. Furthermore, the nonlinear term was significant and explained incremental job tension variance $\left(\beta=.55, \Delta R^{2}=.23, p<.01\right)$. The positive beta at this step indicates a relationship between the independent and dependent variables, characterized by a $U$ shape. The cubic term was not significant $(\beta=.19$, ns). For the high-politics perceptions subgroup, the linear resource management term was not significant $(\beta=.07$, ns), nor was the nonlinear term $(\beta=.01, \mathrm{~ns})$. The cubic term was not significant $(\beta=.03$, ns).

The form of this relationship is shown in Figure 5. This plot was generated using a formula outlined by Cohen and Cohen (1983), who suggested that once evidence of nonlinearity is established, the form of this relationship can be demonstrated by substituting item scores across a range of interests into the quadratic regression equation. In terms of scale scores to include, they advocated "substituting one high and one low value" (Cohen \& Cohen, 1983: 225) as end points. We chose one standard deviation above and below the 
Table 3

Means, Standard Deviations, and Intercorrelations Among Study Variables (Sample 5)

\begin{tabular}{|c|c|c|c|c|c|c|c|c|c|c|}
\hline Variable & Mean & $\begin{array}{l}\text { Standard } \\
\text { Deviation }\end{array}$ & 1 & 2 & 3 & 4 & 5 & 6 & 7 & 8 \\
\hline 1. Age & 40.75 & 11.94 & - & & & & & & & \\
\hline 2. Gender & - & - & -.08 & - & & & & & & \\
\hline 3. Organization tenure & 6.63 & 3.71 & $.41 *$ & -.03 & - & & & & & \\
\hline 4. Position tenure & 3.53 & 3.09 & -.02 & -.05 & $.23 *$ & - & & & & \\
\hline 5. PA & 3.68 & 1.39 & -.02 & .08 & -.03 & $.15^{*}$ & - & & & \\
\hline 6. NA & 1.84 & .79 & .04 & .02 & -.07 & $.23 *$ & $.16^{*}$ & - & & \\
\hline 7. Politics perception & 2.84 & .84 & $-.16^{*}$ & $.23^{*}$ & .02 & .09 & .05 & $.25 *$ & - & \\
\hline 8. Resource management & 3.36 & .63 & .07 & -.05 & .03 & .03 & .01 & $-.16^{*}$ & $-.25 *$ & - \\
\hline 9. Job tension & 2.65 & .74 & -.01 & .03 & .12 & -.01 & -.05 & $.18 *$ & $.30 *$ & $-.28 *$ \\
\hline
\end{tabular}

Note: PA, positive affect; NA, negative affect.

$* p<.05$.

Table 4

Polynomial Regression Analyses (Study 5) Predicting Job Tension

\begin{tabular}{lc}
\hline & Job Tension \\
Step & $\beta$ \\
\hline Step 1 & -.01 \\
Age & .03 \\
Gender & .02 \\
Organization tenure & -.01 \\
Position tenure & $.18^{* *}$ \\
NA & .01 \\
PA & .13 \\
$\Delta R^{2}$ & $.31^{* *}$ \\
Step 2 & $.11^{* *}$ \\
Politics perceptions & -.10 \\
$\Delta R^{2}$ & .01 \\
Step 3 & \\
Politics perceptions ${ }^{2}$ & $-.14^{*}$ \\
$\Delta R^{2}$ & .01 \\
Step 4 &
\end{tabular}

Note: NA, negative affect; PA, positive affect.

$* * p<.01$.

$* p<.05$. 


\section{Figure 5}

The Nonlinear Effects of Politics Perceptions on Job Tension

When Considering Perceived Resources (Sample 5)

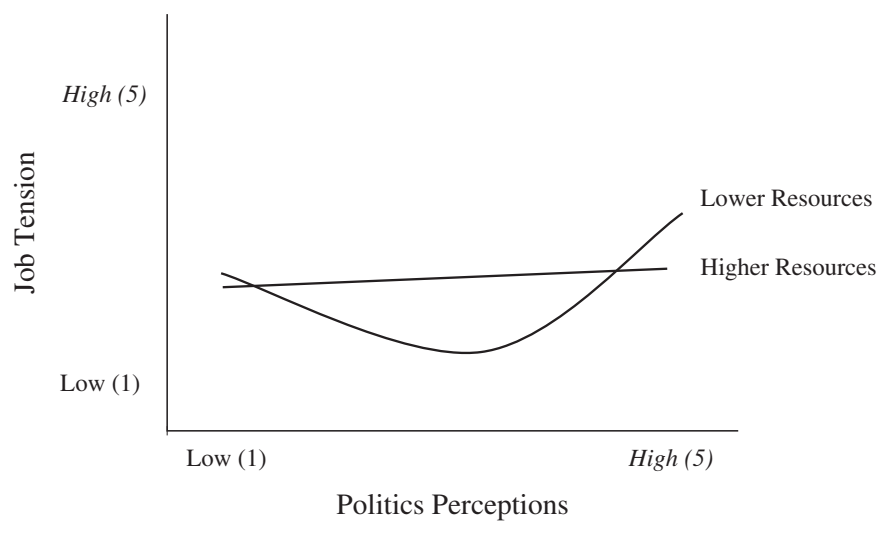

mean as our high and low values for inclusion. Following this, we substituted points within this range to supplement the form of the linear and nonlinear politics perceptions-job tension association. These findings are illustrated in Figure 5. As shown, the relationship between politics perceptions and job tension was virtually unchanged for those with high levels of perceived resources. Conversely, job tension initially decreased then increased as politics perceptions became more evident for those with fewer perceived resources.

\section{Discussion}

Across contexts and occupational groups, we provided evidence that politics perceptions are nonlinearly related to job satisfaction and job tension. Specifically, politics perceptions had its most deleterious effect on job satisfaction and most elevating effects on job tension when both very high and very low. However, further analysis revealed that this nonlinear relationship existed under conditions of lower perceived resources. Taken together, these results confirm the inherent complexity of politics perceptions for both scholarship and practice.

The results reported in this series of studies contribute to, and extend, the existing research base in a number of ways. First, our findings demonstrate that a critical level of politics is needed in the workplace to activate attention and resources toward the achievement of personal and organizational goals. This implies that workplace politics can be both "good" and "bad" (Buchanan, 2008; Ferris \& Hochwarter, in press). Traditionally, scholars have taken the perspectives that politics is either harmful and should be eradicated (Kumar \& Thibodeaux, 1990), or helpful and should be nurtured (Tushman, 1977). As is often the case, charting phenomena in diametrically opposite categories is both inaccurate in terms of reality and a disservice to 
science. Taken together, our findings indicate that it is most appropriate to view politics as a common occurrence in organizations, and critical to managing the process is the cultivation of adequate resource reservoirs (Hochwarter et al., 2007; Hochwarter et al., 2008).

Furthermore, our results suggest that a moderate amount of politics was associated with generally favorable levels of job satisfaction and tension. Fundamentally, it is plausible that some employees simply prefer environments characterized by a modest level of competitive gamesmanship (Buchanan, 2008). Buchanan and Bradham's (1999) idiographic account reported that employees who are the most successful not only enjoy engaging in politics but were also good at it. Moderate levels of politics may allow for an accurate understanding of internal power structures in organizations (Krackhardt, 1990), thus allowing for a more manageable work situation and enhanced satisfaction.

Finally, this series of studies builds on the ever-growing body of research that has conceptualized and empirically tested for nonlinear relational forms previously viewed exclusively as linear (Harris, Kacmar, \& Witt, 2005; Hochwarter et al., 2005). We contend that other streams of research would benefit by expanding their scope of operationalization by taking into account more complex substantive relationships (Ferris et al., 2006).

\section{Strengths and Limitations}

The strengths of this investigation, which consisted of three studies and five samples, require discussion. First, we demonstrated consistent results across diverse settings, replicating nonlinear forms for two practically and theoretically relevant work outcomes (i.e., job satisfaction and job tension). Second, these findings extend our understanding of this phenomenon by illustrating the boundary condition of personal resources, an important condition that neutralizes adverse reactions to stressors (Hobfoll, 1989; Hochwarter et al., 2008). Third, we controlled for affective disposition to minimize their potentially confounding effects (Podsakoff et al., 2003). Fourth, we were able to demonstrate that nonresponse bias was not present in any of the five samples of the three studies. Finally, our research was conducted exclusively in the field, which serves to increase the generalizability of our findings.

Despite these strengths, this research also possesses limitations. First, we are unable to determine causality because of the cross-sectional nature of our samples. It is unlikely that the relationships reported in this research are static. Thus, assessing their initiation and development longitudinally would be helpful. A concern regarding common method bias may be considered because of the manner in which the data were collected (i.e., self-report survey format). However, for common method bias to be judged a hindrance, a pattern of elevated correlations would be apparent. Table 1 does not offer evidence of the spuriously inflated relationships typically associated with method bias effects. Specifically, none of the associations between study variables reached an inordinately high level ( $r>.75$ to. 85; Kline, 1998; Pelled, Eisenhardt, \& Xin, 1999) to suggest construct redundancy.

Finally, we were unable to ascertain the actual cognitive processes that lead to the findings reported in this research. Specifically, our theoretical arguments were based largely on the supposition that politics perceptions were associated with levels of arousal/activation that 
provoke certain reactions. Although these arguments are theoretically viable (Ferris et al., 2006), they were not subjected to rigorous empirical assessment in this research.

\section{Directions for Future Research}

As noted above, research subsequent to this series of studies should seek to explicate the cognitive processes that provoked the reactions documented here. Although we claim (and corroborate in Study 3) that politics perceptions-work outcome relationships are more complex than typically conceptualized (i.e., linearity), it would be insightful to glean a deeper understanding of the mental processes that underscore these reactions. It is likely that person variables, including cognitions, interact with contextual cues in complex ways that have yet to be fully understood.

Furthermore, we illustrated the importance of general workplace resources on one's ability to deal with politics perceptions. However, it may be worthwhile to parse out the effects of individual resources on these stressor-strain relationships. Political skill helps individuals obtain additional resources (Brouer et al., 2006), has been found to counteract the negative effects of a variety of stressors (Perrewé et al., 2005). Therefore, future research should investigate the effects of political skill, and other social acuity measures, on the curvilinear stressor-strain relationships that were established in the present investigation.

Other moderating variables may provide additional insights (Chen \& Fang, 2008). For example, prior research has demonstrated that goal/task difficulty (Christianson, 1992) and neuroticism (Szymura \& Wodniecka, 2003) affect nonlinear arousal-job performance relationships. Theoretically, it can be easily argued that these factors would influence linear and nonlinear politics perceptions-work outcome relationships as well. Finally, the political environment of one's immediate work group may indeed differ from that of the organization as a whole. For example, it is conceivable that immediate supervisors, departmental supervisors, and team leaders uniquely contribute to the ever-changing political culture of their particular work group. Hence, it is expected that both the depth and breadth of political activity are invariant across contexts. Evidence for such a conceptualization comes from Treadway, Adams, and Goodman (2005), who documented the existence of "pockets of politics." Multilevel theories, which take into consideration group- and individual-level perceptions of politics, would be particularly important in this regard (Fedor, Maslyn, Farmer, \& Bettenhausen, 2008; Ferris \& Hochwarter, in press).

\section{Conclusion}

Unlike previous studies, which have demonstrated linear (Ferris et al., 2002; Kacmar \& Baron, 1999) or mixed findings (e.g., Cropanzano et al., 1997; Ferris \& Kacmar, 1992), the present investigation illustrated the importance of widening the scope of politics perceptions-work outcomes relationships by considering nonlinearity. However, despite these findings, we see this research as only the next logical step toward a more informed understanding of both job stress and social influence behavior in organizations. The value of this research will become evident only if it catalyzes others to expand their view of workplace phenomena. 


\section{References}

Aiken, L., \& West, S. 1991. Multiple regression: Testing and interpreting interactions. Newbury Park, CA: Sage.

Aspinwall, L., \& Taylor, S. 1997. A stitch in time: Self-regulation and proactive coping. Psychological Bulletin, 121: 417-436.

Bakker, A., Demerouti, E., \& Euwema, M. 2005. Job resources buffer the impact of job demands on burnout. Journal of Occupational Health Psychology, 10: 170-180.

Baltes, B., Bauer, C., Bajdo, L., \& Parker, C. 2002. The use of multitrait-multimethod data for detecting nonlinear relationships: The case of psychological climate and job satisfaction. Journal of Business and Psychology, 17: 3-17.

Baumann, M., Sniezek, J., \& Buerkle, C. 2001. Self-evaluation, stress and performance: A model of decision making under acute stress. In E. Salas \& G. Klein (Eds.), Linking expertise and naturalistic decision making: 139-158. Mahwah, NJ: Lawrence Erlbaum.

Brayfield, A., \& Rothe, H. 1951. An index of job satisfaction. Journal of Applied Psychology, 35: 307-311.

Brockner, J., Grover, S., Reed, T., \& DeWitt, R. 1992. Layoffs, job insecurity, and survivors' work effort: Evidence of an inverted-U relationship. Academy of Management Journal, 35: 413-425.

Brouer, R., Ferris, G., Hochwarter, W., Laird, M., \& Gilmore, D. 2006. The strain-related reactions to perceptions of organizational politics as workplace stressor: Political skill as a neutralizer. In E. Vigoda-Gadot \& A. Drory (Eds.), Handbook of organizational politics: 187-208. Cheltenham, UK: Edward Elgar.

Buchanan, D. 2008. You stab my back, I'll stab yours: Management experience and perceptions of organizational political behaviour. British Journal of Management, 19: 49-64.

Buchanan, D., \& Badham, R. 1999. Politics and organizational change: The lived experience. Human Relations, 52 : 609-629.

Burke, M., Brief, A., \& George, J. 1993. The role of negative affectivity in understanding relations between selfreports of stressors and strains: A comment on the applied psychology literature. Journal of Applied Psychology, 78: 402-412.

Champoux, J. 1992. A multivariate analysis of curvilinear relationships among job scope, work context satisfaction, and affective outcomes. Human Relations, 45: 87-112.

Chen, Y., \& Fang, W. 2007. The moderating effect of impression management on the organizational politics-performance relationship. Journal of Business Ethics, 79: 263-277.

Christianson, S. 1992. Emotional stress and eyewitness memory: A critical review. Psychological Bulletin, 112: 284-309.

Chung, K., \& Ross, M. 1977. Differences in motivational properties between job enlargement and job enrichment. Academy of Management Review, 2: 113-122.

Cohen, J., \& Cohen, P. 1983. Applied multiple regression/correlation analysis for the behavioral sciences. Hillsdale, NJ: Lawrence Erlbaum.

Cohen, J., Cohen, P., West, S., \& Aiken, L. 2003. Applied multiple regression/correlation analysis for the behavioral sciences. Hillsdale, NJ: Lawrence Erlbaum.

Cohen, S., \& Wills, T. 1985. Stress, social support, and the buffering hypothesis. Psychological Bulletin, 98: 310-357.

Cropanzano, R., Howes, J., Grandey, A., \& Toth, P. 1997. The relationship of organizational politics and support to work behaviors, attitudes, and stress. Journal of Organizational Behavior, 18: 159-180.

Cropanzano, R., \& Li, A. 2006. Organizational politics and workplace stress. In E. Vigoda-Gadot \& A. Drory (Eds.), Handbook of organizational politics: 139-160. Cheltenham, UK: Edward Elgar.

Dawis, R., \& Lofquist, L. 1984. A psychological theory of work adjustment. Minneapolis, MN: University of Minnesota Press.

De Jonge, J., \& Schaufeli, W. 1998. Job characteristics and employee well-being: A test of Warr's Vitamin Model in health care workers using structural equation modeling. Journal of Organizational Behavior, 19: 387-407.

Edwards, J., \& Cooper, J. 1990. The person-environment fit approach to stress: Recurring problems and some suggested solutions. Journal of Organizational Behavior, 11: 293-307.

Fedor, D., Maslyn, J., Farmer, S., \& Bettenhausen, K. 2008. The contribution of positive politics to the prediction of employee reactions. Journal of Applied Social Psychology, 38: 76-96. 
Ferris, G., Adams, G., Kolodinsky, R., Hochwarter, W., \& Ammeter, A. 2002. Perceptions of organizational politics: Theory and research directions. In F. Yammarino \& F. Dansereau (Eds.), Research in multi-level issues, Volume 1: The many faces of multi-level issues: 179-254. Oxford, UK: JAI.

Ferris, G., Bowen, M., Treadway, D., Hochwarter, W., Hall, A., \& Perrewé, P. 2006. The assumed linearity of organizational phenomena: Implications for occupational stress and well-being. In P. Perrewé \& D. Ganster (Eds.), Research in occupational stress and well-being: 205-235. Oxford, UK: JAI.

Ferris, G., Frink, D. Galang, M., Zhou, J., Kacmar, K., \& Howard, J. 1996. Perceptions of organizational politics: Predictors, stress-related implications, and outcomes. Human Relations, 49: 233-266.

Ferris, G., \& Hochwarter, W. (in press). Organizational politics. In S. Zedeck (Ed.), Handbook of industrial/organizational psychology (Vol. 3). Washington, DC: American Psychological Association.

Ferris, G., \& Kacmar, K. 1992. Perceptions of organizational politics. Journal of Management, 18: 93-116.

Ferris, G., Russ, G., \& Fandt, P. 1989. Politics in organizations. In R. Giacalone \& P. Rosenfeld (Eds.), Impression management in the organization: 143-170. Hillsdale, NJ: Lawrence Erlbaum.

Gandz, J., \& Murray, V. 1980. The experience of workplace politics. Academy of Management Journal, 23: 237-251.

Gardner, D. 1986. Activation theory and task design: An empirical test of several new predictions. Journal of Applied Psychology, 71: 411-418.

Gardner, D., \& Cummings, L. 1988. Activation theory and job design: Review and reconceptualization. In B. Staw \& L. Cummings (Eds.), Research in organizational behavior: 81-122. Greenwich, CT: JAI.

Gaudine, A., \& Thorne, L. 2001. Emotion and ethical decision-making in organizations. Journal of Business Ethics, 31: $175-187$.

Halbesleben, J., Osburn, H., \& Mumford, M. 2006. Action research as a burnout intervention: Reducing burnout in the Federal Fire Service. Journal of Applied Behavioral Science, 42: 244-266.

Halbesleben, J., \& Wheeler, A. 2006. The relationship between perceptions of politics, social support, withdrawal, and performance. In E. Vigoda-Gadot \& A. Drory (Eds.), Handbook of organizational politics: 253-270. Cheltenham, UK: Edward Elgar.

Harris, K., \& Kacmar, K. 2003. New directions for research on politics perceptions: Suggestions and an illustrative example. In C. Schreisheim \& L. Neider (Eds.), New directions in human resource management: 91-110. Greenwich, CT: Information Age Publishing.

Harris, K., \& Kacmar, K. 2005. Easing the strain: The buffer role of supervisors in the perceptions of politics-strain relationship. Journal of Occupational and Organizational Psychology, 78: 337-354.

Harris, K., Kacmar, K., \& Witt, L. 2005. The curvilinear relationship between relationship quality and turnover intentions. Journal of Organizational Behavior, 26: 363-378.

Higgins, C., Judge, T., \& Ferris, G. 2003. Influence tactics and work outcomes: A meta-analysis. Journal of Organizational Behavior, 24: 89-106.

Hobfoll, S. 1989. Conservation of resources: A new attempt at conceptualizing stress. American Psychologist, 44: 513-524.

Hobfoll, S. 2001. The influence of culture, community, and the nested-self in the stress process: Advancing conservation of resources theory. Applied Psychology: An International Review, 50: 337-421.

Hobfoll, S., \& Freedy, J. 1993. Conservation of resources: A general stress theory applied to burnout. In W. Schaufeli, C. Maslach, \& T. Marek (Eds.), Professional burnout: Recent developments in theory and research: 115-129. Washington, DC: Taylor \& Francis.

Hochwarter, W. 2003a. The interactive effects of pro-political behavior and politics perceptions on job satisfaction and affective commitment. Journal of Applied Social Psychology, 33: 1360-1378.

Hochwarter, W. 2003b. Social influence and job stress: Direct, intervening, and nonlinear effects. In P. Perrewé \& D. Ganster (Eds.), Research in occupational stress and well being: Exploring theoretical mechanisms and perspectives: 167-206. London, UK: JAI.

Hochwarter, W., Ferris, G., Perrewé, P., Witt, L., \& Kiewitz, C. 2001. A note on the nonlinearity of the age-job satisfaction relationship. Journal of Applied Psychology, 31: 1223-1237.

Hochwarter, W., Laird, M., \& Brouer, R. 2008. Board up the windows: The interactive effects of hurricane-induced job stress and perceived resources on work outcomes. Journal of Management, 34: 263-269.

Hochwarter, W., Perrewé, P., Hall, A., \& Ferris, G. 2005. Negative affectivity as a moderator of the form and magnitude of the relationship between felt accountability and job tension. Journal of Organizational Behavior, 26: $517-535$ 
Hochwarter, W., Perrewé, P., Meurs, J., \& Kacmar, C. 2007. The interactive effects of work-induced guilt and ability to manage resources on job and life satisfaction. Journal of Occupational Health Psychology, 12: 125-135.

Hochwarter, W., \& Treadway, D. 2003. The interactive effects of negative and positive affect on the politics perceptions-job satisfaction relationship. Journal of Management, 29: 551-567.

House, R., \& Rizzo, J. 1972. Role conflict and ambiguity as critical variables in a model of organizational behavior. Organizational Behavior and Human Performance, 7: 467-505.

Isen, A., Daubman, K., \& Nowicki, G. 1987. Positive affect facilitates creative problem solving. Journal of Personality and Social Psychology, 51: 1122-1131.

Ito, J., \& Brotheridge, C. 2003. Resources, coping strategies, and emotional exhaustion: A conservation of resources perspective. Journal of Vocational Behavior, 63: 490-509.

Janssen, O. 2001. Fairness perceptions as a moderator in the curvilinear relationships between job demands, and job performance and job satisfaction. Academy of Management Journal, 44: 1039-1050.

Judge, T., Ilies, R., \& Scott, B. 2006. Work-family conflict and emotions: Effects at work and at home. Personnel Psychology, 59: 779-815.

Kacmar, K., \& Baron, R. 1999. Organizational politics: The state of the field, links to related processes, and an agenda for future research. In G. Ferris (Ed.), Research in personnel and human resources management: 1-39. Stamford, CT: JAI.

Karasek, R. 1979. Job demands, job decision latitude, and mental strain: Implications for job redesign. Administrative Science Quarterly, 24: 285-309.

Kline, R. 1998. Principles and practice of structural equation modeling. New York: Guilford.

Krackhardt, D. 1990. Assessing the political landscape: Structure, cognition, and power in organizations. Administrative Science Quarterly, 35: 342-369.

Kumar, K., \& Thibodeaux, M. 1990. Organizational politics and planned organizational change. Group and Organizational Studies, 15: 357-365.

Latack, J., \& Havlovic, S. 1992. Coping with job stress: A conceptual evaluation framework for coping measures. Journal of Organizational Behavior, 13: 479-508.

Locke, E. 1976. The nature and causes of job satisfaction. In M. Dunnette (Ed.), Handbook of industrial and organizational psychology: 1297-1349. Chicago: Rand McNally.

Miller, B., Rutherford, M., \& Kolodinsky, R. 2008. Perceptions of organizational politics: A meta-analysis of outcomes. Journal of Business and Psychology, 22: 209-222.

Mintzberg, H. 1983. Power in and around organizations. Englewood Cliffs, NJ: Prentice Hall.

Neisser, U. 1976. Cognition and reality: Principles and implications of cognitive psychology. San Francisco, CA: Freeman.

Nelson, D., Quick, J., \& Hitt, M. 1989. Men and women of the personnel profession: Some differences and similarities in their stress. Stress Medicine, 5: 145-152.

Pelled, L., Eisenhardt, K., \& Xin, K. 1999. Exploring the black box: An analysis of work group diversity, conflict, and performance. Administrative Science Quarterly, 44: 1-28.

Perrewé, P., \& Spector, P. 2002. Personality research in the organizational sciences. In G. Ferris \& J. Martocchio (Eds.), Research in personnel and human resources management: 1-85. Oxford, UK: JAI.

Perrewé, P., Zellars, K., Rossi, A., Ferris, G., Kacmar, C., Liu, Y., et al. 2005. Political skill as a form of control: An antidote in the role overload-strain relationship. Journal of Occupational Health Psychology, 10: 239-250.

Podsakoff, P., MacKenzie, S., Lee, J., \& Podsakoff, N. 2003. Common method biases in behavioral research: A critical review of the literature and recommended remedies. Journal of Applied Psychology, 88: 879-903.

Rosen, C., Levy, P., \& Hall, R. 2006. Placing perceptions of politics in the context of the feedback environment, employee attitudes, and job performance. Journal of Applied Psychology, 91: 211-220.

Rosenthal, R. 1979. The "file drawer problem" and tolerance for null results. Psychological Bulletin, 86: 638-641.

Salancik, G., \& Pfeffer, J. 1978. A social information processing approach to job attitudes and job design. Administrative Science Quarterly, 23: 224-254.

Scott, W. 1966. Activation theory and task design. Organizational Behavior and Human Performance, 1: 32-50.

Selye, H. 1976. The stress of life. New York: McGraw-Hill.

Shinn, M., \& Rapkin, B. 2000. Cross-levels research without cross-ups in community psychology. In J. Rappaport \& E. Seidman (Eds.), Handbook of community psychology: 697-724. New York: Plenum. 
Singh, J. 1998. Striking a balance in boundary-spanning positions: An investigation of some unconventional influences of role stressors and job characteristics on job outcomes of salespeople. Journal of Marketing, 62: 69-86.

Stimson, J., Carmines, E., \& Zeller, R. 1981. Interpreting polynomial regression. In P. Marsden (Ed.), Linear models in social research: $88-96$. Beverly Hills, CA: Sage.

Szymura, B., \& Wodniecka, Z. 2003. What really bothers neurotics? In search for factors impairing attentional performance. Personality and Individual Differences, 34: 109-126.

Thoresen, C., Kaplan, S., Barsky, A., Warren, C., \& de Chermont, K. 2003. The affective underpinnings of job perceptions and attitudes: A meta-analytic review and integration. Psychological Bulletin, 129: 946-972.

Treadway, D., Adams, G., \& Goodman, J. 2005. The formation of political sub-climates: Predictions from social identity, structuration, and symbolic interaction. Journal of Business and Psychology, 20: 201-219.

Treadway, D., Ferris, G., Hochwarter, W., Perrewé, P., Witt, L., \& Goodman, J. 2005. The role of age in the perceptions of politics-job performance relationship: A three-study constructive replication. Journal of Applied Psychology, 90: 872-881.

Tsui, A. 1999. From the editor. Academy of Management Journal, 42: 589-590.

Tushman, M. 1977. Special boundary roles in the innovation process. Administrative Science Quarterly, 22: 587-605.

Watson, D., Clark, L., \& Tellegen, A. 1988. Development and validation of brief measures of positive and negative affect: The PANAS Scales. Journal of Personality and Social Psychology, 6: 1063-1070.

Warr, P. 1987. Work, unemployment and mental health. Oxford, UK: Clarendon Press.

Warr, P. 1990. Decision latitude, job demands, and employee well-being. Work and Stress, 4: 285-294.

Warr, P. 1994. A conceptual framework for the study of work and mental health. Work and Stress, 8: 84-97.

Weick, K. 1995. Sensemaking in organizations. Thousand Oaks, CA: Sage.

Westman, M., \& Etzion, D. 2002. The impact of short overseas business trips on job stress and burnout. Applied Psychology: An International Review, 51: 582-592.

Witt, L., Andrews, M., \& Kacmar, K. 2000. The role of participation in decision-making in the organizational politics-job satisfaction relationship. Human Relations, 53: 341-358.

Xie, J., \& Johns, G. 1995. Job scope and stress: Can job scope be too high? Academy of Management Journal, 38 : 1288-1309. 